gas companies will not rush out to drill more wells just because prices are rising. A Chase Manhattan Bank study of the question concluded that "the legislation could actually result in some weakening of the dollar as foreign exchange markets come to perceive that the long-run supply of natural gas in the U.S. is as likely to be reduced as increased." And at least two senators have announced plans to oppose the bill because of their opposition to breeder reactors, now linked to it.

The Carter-McClure compromise is also likely to broaden the debate over conduct of the entire breeder reactor programme. Work is still not complete on the Fast Flux Test Facility, (FFTF) a non-power-generating breeder reactor meant to be a forerunner of Clinch River. First authorised in 1967, FFTF was originally estimated to cost only $\$ 87.5$ million but has already passed the billion dollar mark. The CRBR has also experienced severe delays and cost overruns, and both industry and Congressional sources tell Nature that any further delay would probably result in a re-evaluation of the basic American breeder design.

During the debate over whether breeder reactors should be built at all, many technologists have reportedly swallowed their specific objections to the CRBR design in hopes of not exacerbating the issue. Specifically, they favour a reactor in which the radioactive molten sodium that passes through the core never leaves the re- actor vessel and one in which steam for generating electricity is handled at a lower temperature and pressure than now called for. If the Clinch River project is deferred or cancelled in favour of producing a later-and probably larger-reactor, such arguments will probably become much more audible.

It is hard to recall a time when the US energy picture has appeared more cloudy. After he had calmed his initial anger, about the best Senator Baker could say for the recent compromise was "the water has been muddied". All that remains certain is that both the natural gas regulation and breeder reactor issues will take on new dimensions when Congress returns from its present Labour Day recess.

\section{Boycott of Soviet contacts is for individuals, says NAS}

RECENT 'human rights' trials of scientists in the Soviet Union resulted in the immediate cancellation of several major visits by US scientists to the Soviet Union-and these in turn have provoked a biting reaction from the Soviet media-a sure sign that the threat of a severance of scientific relations was a real one. "Future historians will be amazed" wrote the Literaturnaya Gazeta, that such reprisals could be contemplated as a means of making the USSR give up "the principles which are sacred to it."

This reaction would appear to sub stantiate the case for boycott, a case most ably put by Valentin Turchin (Nature 273, 256-257; 1978). Not all scientists would support this view, feeling that continuation of contacts makes it possible to express one's concern with the fate of, say, Orlov and Shcharanskii, at least on the personal level, to Soviet colleagues encountered at international conferences.

Thus last month, when the Inter. national Congress of Mathematicians was held in the "human rights" city of Helsinki, right on the Soviets' doorstep (subsidised excursions to Leningrad were laid on as a side attraction), several Soviet mathematicians failed to arrive to deliver their papers. One of these people, a Dr Margulis, was scheduled to receive a medal. The ceremony was carried out in his absence, and the formal "presentation" of his work was greeted by a standing ovation, pinpointing in a telling manner the persistent Soviet practice of denying visas to scientists invited to international conferences.

Many would see the stricter insistence on the norms of scientific lifeincluding proper representation at con- ferences, a more fitting form of protest than an all-out or selective boycott.

Respecting the diversity of views on boycott, the US National Academy of Sciences recently put out a statement calling on world scientists to urge the release of Orlov, Shcharanskii and Sergei Kovalev, a biologist now halfway through a sentence of seven years in a labour camp. The Human Rights Committee of the Academy said:

"These scientists, along with fourteen others in other parts of the world, are of particular concern to this committee, for they represent numbers of colleagues who believe that freedom of intellectual inquiry cannot be divided into two parts-one for the natural world in which we live and one for the society which nurtures us-and who have been imprisoned for acting in accordance with their beliefs".

Nevertheless, the Academy stressed that it does not, as a body, endorse boycotts. "Each American scientist", it concludes, "contemplating a visit to the USSR (or asked to host a Soviet scientist in the US) must determine his or her own course of action."

Interestingly, this decision follows an opposite course to that advocated by a group of French physicists last July, who advocated the severance of all official scientific relations-including conferences-while maintaining personal contacts with Soviet colleagues, making the latter the "occasion of expressing our indignation".

The NAS acceptance of individual choice of protest also underlies the concluding paragraph of a moving appeal which recently reached the West from Kovalev's son, Ivan. Addressing the intending participants of the Fourteenth International Congress of
Genetics in Moscow, he outlined the history of his father's case, and gave a vivid and horrifying picture of prison conditions, he asked for the participants' support, that they would express their attitude towards the imprisonment of their colleague "by means appropriate to you". The appeal has since been circulated by campaigners for boycott, but it is noteworthy that neither Amnesty International, who distributed the letter, nor Ivan Kovalev himself, specifically ask for this.

Nevertheless, the idea of at least a selective boycott does seem to be taking hold in the USA. According to the NAS, its supporters "include scientists who pioneered in the earliest Soviet/ US exchanges, seeking to build bridges of common scientific endeavour across the chasm of the cold war. They also include others who have seen themselves as steadfast in resisting the politicisation of science. People have reached their decisions in varied ways: sadness, rather than anger has been the most common emotion".

It is because the response of US scientists is so "individualistic", concludes the Academy, that continued Soviet-US scientific relations are in peril. "Scientific exchange programmes" it says "can be negotiated and organised, but individual participation cannot be commanded. There has been no institutional instruction or decision making. no rush to judgment, and no stampede to boycott. Rather there is a tide of spontaneous response running deep, and it will not be easily reversed in the absence of some iudicious and humanitarian actions by Soviet authorities".

Vera Rich 